\title{
Dust and sea salt variability in central East Antarctica (Dome C) over the last 45 kyrs and its implications for southern high-latitude climate
}

\author{
Regine Röthlisberger, ${ }^{1,2}$ Robert Mulvaney, ${ }^{1}$ Eric W. Wolff ${ }^{1}$ Manuel A. Hutterli ${ }^{3}$ \\ Matthias Bigler, ${ }^{2}$ Stefan Sommer, ${ }^{2}$ and Jean Jouzel ${ }^{4}$ \\ Received 21 March 2002; accepted 24 June 2002; published 22 October 2002.
}

[1] A detailed record of non-sea-salt calcium, a proxy for dust, and sea-salt sodium, a proxy for sea salt, covering the last $45 \mathrm{kyr}$ is presented. It shows that in the first part of the transition from the last glacial period to the Holocene (18$15 \mathrm{kyr} \mathrm{BP})$, the changes in dust flux mainly reflect changes at the dust source, namely vegetation cover and local climate. The changes in the later part of the transition (12$11 \mathrm{kyr}$ BP) are similar in extent to the changes seen in sea salt and most likely reflect a reorganization of the atmospheric circulation. During the last glacial period, considerable variation of dust but not of sea salt is observed, pointing to climatic changes in Patagonia, the main dust source for Dome C. A comparison of the glacial records from Dome $\mathrm{C}$ and Taylor Dome suggests that similar influences controlled aerosol input at both sites during this period. INDEX TERMS: 3344 Meteorology and Atmospheric Dynamics: Paleoclimatology; 1620 Global Change: Climate dynamics (3309); 9310 Information Related to Geographic Region: Antarctica; 0368 Atmospheric Composition and Structure: Troposphere-constituent transport and chemistry. Citation: Röthlisberger, R., R. Mulvaney, E. W. Wolff, M. A. Hutterli, M. Bigler, S. Sommer, and J. Jouzel, Dust and sea salt variability in central East Antarctica (Dome C) over the last 45 kyrs and its implications for southern high-latitude climate, Geophys. Res. Lett., 29(20), 1963, doi:10.1029/2002GL015186, 2002.

\section{Introduction}

[2] Dust and sea salt records from polar ice cores have been widely used to infer past changes in atmospheric circulation and climatic conditions in the source region as well as in the Antarctic (e.g., [Legrand et al., 1988; Steig et al., 2000]) and have served as a control for atmospheric general circulation model (AGCM) simulations of atmospheric dust distribution in the past [Reader et al., 1999; Mahowald et al., 1999]. Generally, higher levels of impurities have been observed during the last glacial period in all Antarctic ice cores. The large increase in dust is assumed to be caused by increased production in the dust source region and more vigorous transport. Sea salt concentrations are

\footnotetext{
${ }^{1}$ British Antarctic Survey, Cambridge, England, UK.

${ }^{2}$ Climate and Environmental Physics, University of Bern, Bern, Switzerland.

${ }^{3}$ Department of Hydrology and Water Resources, University of Arizona, Tucson, Arizona, USA.

${ }^{4}$ Laboratoire des Sciences du Climat et de l'Environnement, Gif-surYvette, France.
}

Copyright 2002 by the American Geophysical Union. 0094-8276/02/2002GL015186\$05.00 thought to be influenced by the sea ice position and wind speed in the potential source region as well as the transport from there to the ice core site.

[3] Compared to Greenland ice core records, the Antarctic dust and sea salt records showed much smaller variations during the last glacial period [Legrand et al., 1988; Legrand and Delmas, 1988], which may at least partially be attributed to limited resolution. The only Antarctic record showing marked variation of dust and sea salt during the last glacial period was from Taylor Dome, a site next to the Ross ice shelf, thus relatively close to the coast and possibly susceptible to regional climate changes [Steig et al., 2000].

[4] Here we present the first high-resolution record of calcium $\left(\mathrm{Ca}^{2+}\right.$, a proxy for dust [Fuhrer et al., 1999]) and sodium $\left(\mathrm{Na}^{+}\right.$, a proxy for sea salt) together with deuterium $(\delta \mathrm{D})$ from an inland Antarctic site. The drilling in the frame of the European Project for Ice Coring in Antarctica (EPICA) at Dome C $\left(75^{\circ} 06^{\prime} \mathrm{S}, 123^{\circ} 24^{\prime} \mathrm{E}, 3233 \mathrm{~m}\right.$ a.s.l., approximately $1100 \mathrm{~km}$ from the nearest coast) reached a depth of $780 \mathrm{~m}$ by the end of the 1998/99 field season, corresponding to an age of approximately 45 kyrs [Schwander et al., 2001]. The detailed records are discussed in terms of changes in aerosol source and transport and compared to the near-coastal records from Taylor Dome.

\section{Methods}

[5] $\mathrm{Ca}^{2+}$ and $\mathrm{Na}^{+}$were analysed using a continuous flow analysis system (CFA) [Röthlisberger et al., 2000]. Generally, the detection limit was of the order of less than $1 \mathrm{ppb}$ for $\mathrm{Ca}^{2+}$ and a few ppb for $\mathrm{Na}^{+}$. There may be some intervals with larger uncertainty due to unstable conditions of the analytical system, but a comparison with ion-chromatographic methods has shown a good overall agreement [Littot et al., 2002]. Apart from $200 \mathrm{~m}$ that have been analysed with the same setup at the Alfred Wegener Institute in Bremerhaven, Germany in 2000, all analyses were made at Dome C during the 1997/98 and 1998/99 field seasons. $\delta \mathrm{D}$ measurements were carried out in Saclay, France using the uranium reduction technique and an automatic sample injection device [Vaughn et al., 1998].

\section{Results and Discussion}

[6] As some of the $\mathrm{Ca}^{2+}$ found in the ice at Dome $\mathrm{C}$ is of marine origin, the $\mathrm{Ca}^{2+}$ concentrations reflect changes in dust and in sea salt levels. Similarly, some $\mathrm{Na}^{+}$derives from continental dust. Assuming a $\mathrm{Ca}^{2+} / \mathrm{Na}^{+}$ratio of 0.038 for marine aerosols $\left(\mathrm{R}_{m}\right)$ and 1.78 for average crust $\left(\mathrm{R}_{t}\right)$ [Bowen, 1979], we calculated the sea-salt- $\mathrm{Na}^{+}\left(\mathrm{ss}-\mathrm{Na}^{+}=\right.$ $\left.\mathrm{Na}^{+}-\frac{\text { nss- }-\mathrm{Ca}^{2+}}{R_{t}}\right)$ and the non-sea-salt-Ca ${ }^{2+}\left(\right.$ nss- $-\mathrm{Ca}^{2+}=\mathrm{Ca}^{2+}$ 


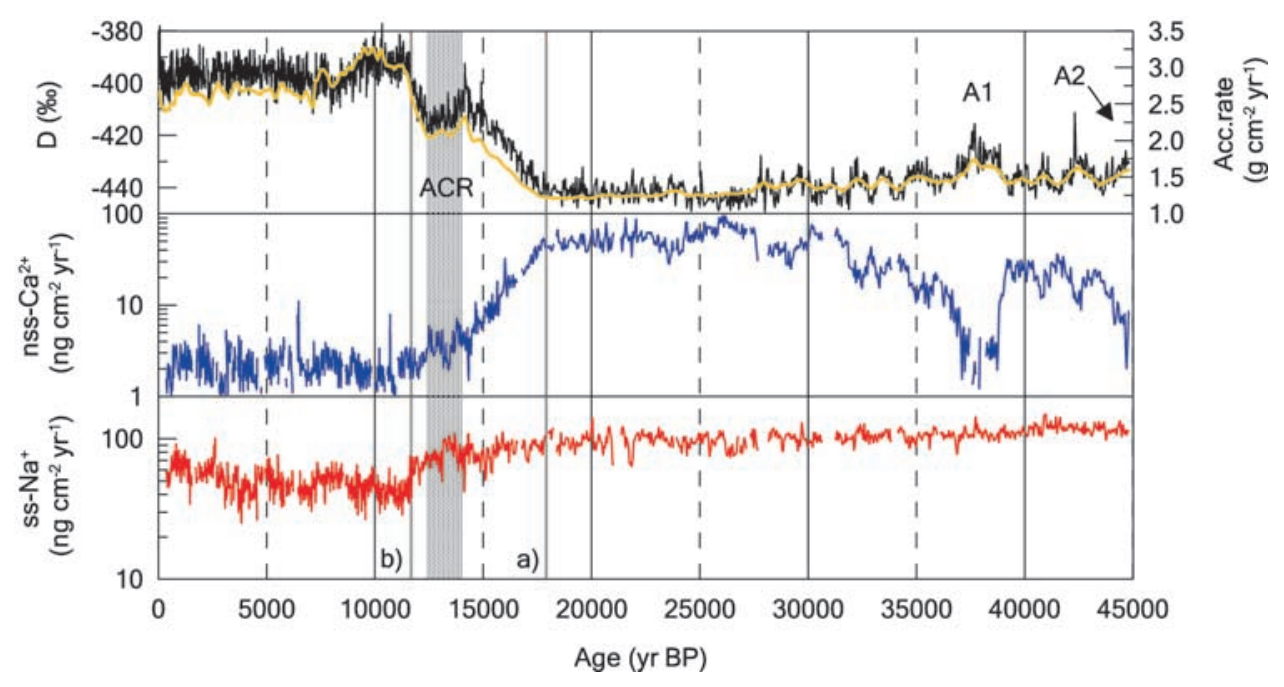

Figure 1. Fluxes of ss- $-\mathrm{Na}^{+}$and nss- $-\mathrm{Ca}^{2+}$, as well as the $\delta \mathrm{D}$ and the accumulation rate (yellow line, [Schwander et al., 2001]) from the top $780 \mathrm{~m}$ of the EPICA Dome $C$ deep ice core at $55 \mathrm{~cm}$ resolution. The vertical grey lines refer to the beginning (a) and the end (b) of the Transition, the shaded area corresponds to the Antarctic Cold Reversal (ACR).

$-R_{m} \cdot \mathrm{ss}-\mathrm{Na}^{+}$). In the Holocene, the terrestrial input at Dome $\mathrm{C}$ is extremely low, the marine contribution to $\mathrm{Ca}^{2+}$ is around $50 \%$ and the terrestrial $\mathrm{Na}^{+}$is of the order of $2 \%$. During the last glacial maximum (LGM, 18-24 kyr B.P.), only $7 \%$ of $\mathrm{Ca}^{2+}$ came from sea salt, whereas $24 \%$ of $\mathrm{Na}^{+}$ came from terrestrial dust. However, the $\mathrm{Ca}^{2+} / \mathrm{Na}^{+}$ratio varies for different types of terrestrial material. We did the above calculation also for average soil and average sediment $\mathrm{Ca}^{2+} / \mathrm{Na}^{+}$ratios. This led to similar percentages for Holocene and glacial ss-Ca ${ }^{2+}$ and Holocene nss- $\mathrm{Na}^{+}$, while the glacial nss- $\mathrm{Na}^{+}$ranged from $3 \%$ to $24 \%$ depending on the $\mathrm{Ca}^{2+} / \mathrm{Na}^{+}$ratio used. However, based on aluminium measurements [Legrand and Delmas, 1988], the ratio for the average crust seems to be the most suitable value and was thus used to calculate nss- $\mathrm{Ca}^{2+}$ and ss- $\mathrm{Na}^{+}$.

[7] In agreement with previous results obtained from Antarctic ice cores (e.g., [Steig et al., 2000; Legrand et al., 1988; Legrand and Delmas, 1988; Watanabe et al., 1999]), nss-Ca ${ }^{2+}$ and ss- $\mathrm{Na}^{+}$concentrations in the Dome C record were higher during the last glacial period. At the LGM, nss- $\mathrm{Ca}^{2+}$ concentrations were approximately 50 times higher than during the Holocene, and ss- $\mathrm{Na}^{+}$approximately 5 times. During the transition, nss- $\mathrm{Ca}^{2+}$ and $\mathrm{ss}-\mathrm{Na}^{+}$ concentrations decreased steadily from glacial levels to a relatively stable level during the Antarctic Cold Reversal (ACR, 14-12.5 kyr B.P.), and then further to Holocene levels. Concentrations of nss- $\mathrm{Ca}^{2+}$ changed by a factor of 23 from LGM to ACR levels, while ss- $\mathrm{Na}^{+}$concentrations decreased only by a factor of 2 . Both nss- $\mathrm{Ca}^{2+}$ and $\mathrm{ss}-\mathrm{Na}^{+}$ concentrations dropped further by a factor of 2.3 from the ACR to the early Holocene. The changes seen in nss-Ca ${ }^{2+}$ concentrations agree with insoluble dust measurements [Delmonte et al., 2001], with particle number and mass concentration changing by a factor of 50 from the LGM to the Holocene and a factor of 2 from the ACR to the Holocene.

[8] At Dome C, the accumulation rate is very low $(2.7 \mathrm{~g}$ $\mathrm{cm}^{-2} \mathrm{yr}^{-1}$, [Schwander et al., 2001]) and was reduced by a factor of approximately 2 during the last glacial period. Since there is so little precipitation, dry deposition is the dominating process for sea salt and dust deposition [Legrand, 1987]. In order to compensate as well as possible for the dilution effect of changes in the accumulation rate, we consider the changes in nss- $\mathrm{Ca}^{2+}$ and $\mathrm{ss}-\mathrm{Na}^{+}$flux calculated with the accumulation rates of Schwander et al., 2001 in the following discussion.

\subsection{Transition}

[9] The ss- $\mathrm{Na}^{+}$flux was almost constant during the last glacial period and changed only by a factor of 2 from the LGM to the early Holocene (Figure 1). Most of the changes during the transition happened after the ACR [Stenni et al., 2001]. nss-Ca ${ }^{2+}$ flux on the other hand changed dramatically in the early phase of the transition, and the change from the ACR to the Holocene was of similar extent as for ss- $\mathrm{Na}^{+}$. According to a recent study of dust transport to Dome $\mathrm{C}$ based on back trajectory calculations [Lunt and Valdes, 2001], the dust transport was reduced during the LGM. These results are supported by dust particle measurements [Delmonte et al., 2001], which showed a slightly smaller particle mode and a smaller geometric standard deviation of the particle size distribution in the glacial than in the Holocene, indicative of a tendency to longer transport paths and less meridional transport. On the other hand, based on GCM simulations Krinner and Genthon [2002] concluded that the dust transport from Patagonia to Dome C was faster during the LGM, in contrast to the studies by Lunt and Valdes [2001] and Delmonte et al. [2001]. But at any rate, based on these studies the changes in dust transport to Antarctica were small and cannot account for the large changes seen in dust. Therefore, substantial changes at the dust source, which is believed to be mainly located in Patagonia [Basile et al., 1997], must have occurred in order to explain the high dust input during the LGM and the different behaviour of $\mathrm{nss}-\mathrm{Ca}^{2+}$ and $\mathrm{ss}-\mathrm{Na}^{+}$during the transition.

[10] The potential dust source area decreased with rising sea level, but the period of rapid sea level rise (around 14 kyr BP [Guilderson et al., 2000]) coincides with a period of almost no changes in dust, suggesting that the contribution 
from continental shelves to the total dust transported to Dome $\mathrm{C}$ is not dominant. This is in agreement with a study comparing the isotopic composition of dust from the Argentine continental shelf and the dust from Dome $\mathrm{C}$ and Vostok [Basile et al., 1997]. Based on various palaeoenvironmental proxies, Patagonia experienced a warming and a concomitant glacier retreat around 17,330 yr BP (e.g., McCulloch and Davis, [2001] and references therein). The warmer climate promoted vegetation growth, which was supported by an increase in effective moisture around 16,910 yr BP [McCulloch and Davis, 2001]. Therefore, dust entrainment was hindered by soil moisture and vegetation cover, which led to a decrease in aeolian dust as observed in the Dome $\mathrm{C}$ record. Changes in local wind speed might have had an influence on dust uplift as well, with lower wind speeds leading to less dust. From 15,330 yr BP to approximately 12,200 yr BP, McCulloch and Davis [2001] report a relatively dry phase, accompanied by glacier advances. During this period (ACR), the nss- $\mathrm{Ca}^{2+}$ fluxes at Dome $\mathrm{C}$ remained more or less constant. Around 12,200 yr BP, trees and shrubs started to spread, indicating a second warming step in southern South America. However, this second warming was not paralleled by an increase in precipitation, but a relatively dry climate prevailed for several millennia. Nonetheless the nss-Ca ${ }^{2+}$ flux at Dome $\mathrm{C}$ decreased further between the ACR and the Holocene by almost a factor of 2. As the change is similar to the changes seen in ss- $\mathrm{Na}^{+}$, we suggest that a reorganization of the atmospheric circulation led either to changes in transport or source fluxes at both the dust and sea salt source.

\subsection{5 to 45 kyr B.P.}

[11] In the earlier part of the last glacial period, from 45 to approximately $25 \mathrm{kyr}$ B.P., the $\delta \mathrm{D}$ record showed a few distinct oscillations. These variation in stable isotopes have been observed in other Antarctic ice cores [Blunier et al., 1998] and have been referred to as A1 and A2 (Figure 1). The nss-Ca ${ }^{2+}$ flux changed considerably during these two major events, but even on a shorter timescale, it parallels the minor variations seen in $\delta \mathrm{D}$ (Figure 1). The ss- $\mathrm{Na}^{+}$flux on the other hand seems unaffected by these changes.

[12] As seen in Figure 2, the lowest nss-Ca ${ }^{2+}$ fluxes during the oscillations in the glacial period were as low as during the Holocene. At 39 kyr B.P., nss- $\mathrm{Ca}^{2+}$ flux dropped

\section{$+\quad$ Holocene $(0-11.5$ kyr BP) \\ Transition (11.5 - $18 \mathrm{kyr} \mathrm{BP})$ ․ Glacial (18 - 45kyr BP)}

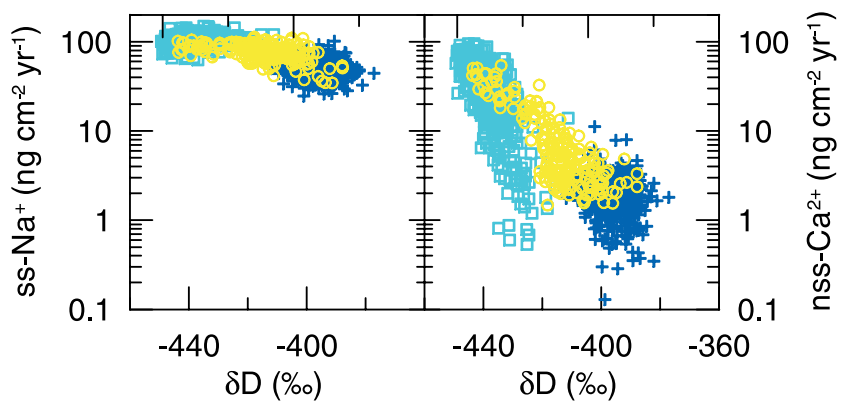

Figure 2. Fluxes of ss- $\mathrm{Na}^{+}$and $\mathrm{nss}_{-}-\mathrm{Ca}^{2+}$ versus $\delta \mathrm{D}, 55 \mathrm{~cm}$ averages.

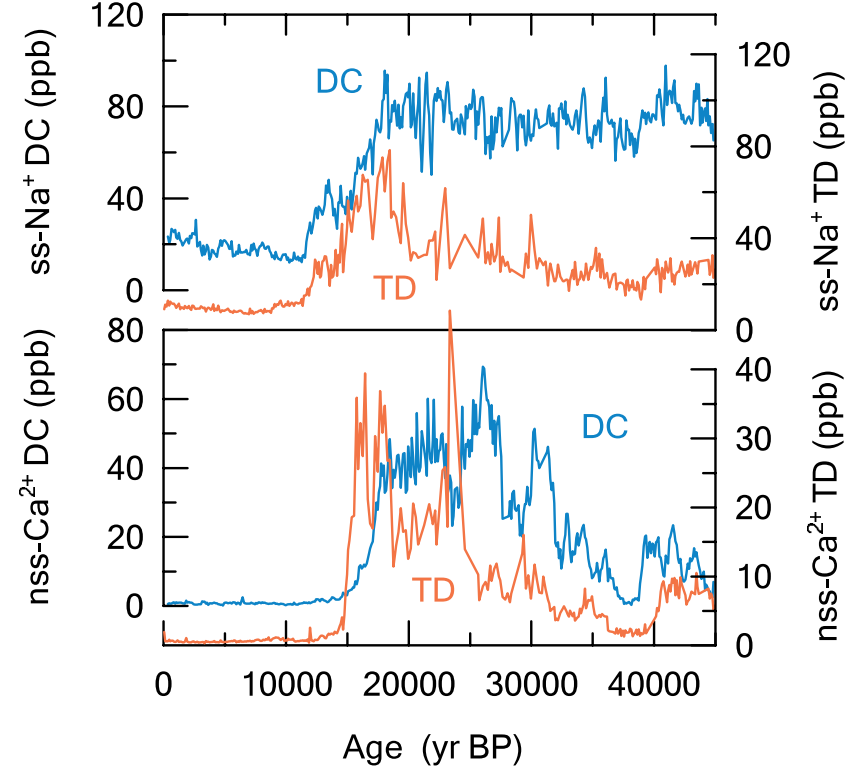

Figure 3. Concentrations of $\mathrm{ss}-\mathrm{Na}^{+}$and nss-Ca ${ }^{2+}(100-\mathrm{yr}$ averages) from Dome $\mathrm{C}$ and Taylor Dome [Steig et al., 2000].

from 30 to $3 \mathrm{ng} \mathrm{cm}^{-2} \mathrm{yr}^{-1}$ within approximately 400 years. In contrast to nss-Ca ${ }^{2+}$, the variation in the $\mathrm{Ss}^{-\mathrm{Na}^{+}}$flux during the glacial period was small compared to the change from glacial to Holocene ice. The fact that sea salt fluxes were doubled during the last glacial period compared to the Holocene despite the expansion of sea ice indicates that atmospheric circulation and the hydrological cycle are most likely the factors dominating sea salt aerosol flux at Dome C. Major changes in these two factors should therefore be reflected in ss- $\mathrm{Na}^{+}$as well as nss-Ca ${ }^{2+}$. Thus, the cause of the glacial flux changes only seen in $\mathrm{nss}^{-\mathrm{Ca}^{2+}}$ must lie instead in Patagonia, analogous to the above discussion of the transition. This implies drastic changes in southern Patagonian climate during the last glacial period, most likely in temperature and precipitation, that were coeval with changes in temperature at Dome $\mathrm{C}$.

[13] In Figure 3, we compare the nss-Ca ${ }^{2+}$ and $\mathrm{ss}-\mathrm{Na}^{+}$ concentrations of Dome $\mathrm{C}$ with the ones measured at Taylor Dome [Steig et al., 2000]. The data are shown as 100-yr averages based on the st9810 timescale. However, Mulvaney et al. [2000] have shown that this timescale needs to be revised around the transition from the LGM to the Holocene. We therefore only refer to the general shape of the nss- $-\mathrm{Ca}^{2+}$ and $\mathrm{ss}-\mathrm{Na}^{+}$records but not to the timing of the changes. Sea salt and dust concentrations were higher at Dome $\mathrm{C}$ than at Taylor Dome by about a factor of 2, which reflects most likely the dilution effect of higher accumulation rates at Taylor Dome than at Dome C. While one would expect that large changes in dust input would manifest at Dome $\mathrm{C}$ and Taylor Dome in a similar way [Mulvaney et al., 2000], it is rather surprising that also the general shape of the sea salt records of both sites are similar, as the sea salt source is so much closer to Taylor Dome than to Dome C. However, empirical orthogonal function (EOF) analysis of the chemical records from Taylor Dome has shown that the dominant EOF, which is thought to reflect 
atmospheric circulation systems, explains more than $90 \%$ of the variability of sodium and calcium [Steig et al., 2000] The similarity of the sea salt as well as the dust records of the two sites during the last glacial period suggests that not only sea salt and dust aerosol were closely linked through large-scale circulation patterns, but that this influenced primary aerosol input to central and near coastal Antarctica in a similar way.

\section{Conclusions}

[14] The dust record of the EPICA ice core from Dome C is closely linked with palaeoclimatic records from southern Patagonia during the transition from the last glacial period to the Holocene. The vast changes by a factor of 24 in nss$\mathrm{Ca}^{2+}$ flux observed in the early part of the transition reflect changes in vegetation cover and soil moisture in Patagonia that prevented dust uplift. During the last glacial period, considerable changes in the nss-Ca ${ }^{2+}$ flux are observed, but no changes in $\mathrm{ss}-\mathrm{Na}^{+}$. It is unlikely that the massive changes in atmospheric transport that would be necessary to cause the changes in dust flux would not be reflected in $\mathrm{ss}-\mathrm{Na}^{+}$. Therefore, the nss-Ca ${ }^{2+}$ record from Dome C documents relatively rapid climatic changes in southern South America, coeval with temperature variations at Dome C. The nss- $\mathrm{Ca}^{2+}$ as well as the ss-Na ${ }^{+}$records from Dome C and Taylor Dome are very similar in form during the last glacial period, with little variation in the sea salt concentration in contrast to huge changes in dust, indicating similar influences controlling aerosol input in near coastal and central Antarctica.

[15] Acknowledgments. This work is contribution No. 491 to the "European Project for Ice Coring in Antarctica" (EPICA), a joint ESF (European Science Foundation)/EC scientific programme, funded by the European Commission and national contributions from Belgium, Denmark, France, Germany, Italy, the Netherlands, Norway, Sweden, Switzerland, and the United Kingdom. R. R. thanks the SNF for financial support and J. Schwander for valuable discussion and providing data.

\section{References}

Basile, I., F. E. Grousset, M. Revel, J. R. Petit, P. E. Biscaye, and N. I. Barkov, Patagonian origin of glacial dust deposited in East Antarctica (Vostok and Dome C) during glacial stages 2, 4, and 6, Earth Planet. Sci. Lett., 146, 573-589, 1997.

Blunier, T., J. Chappellaz, J. Schwander, A. Dällenbach, B. Stauffer, T. F. Stocker, D. Raynaud, J. Jouzel, H. B. Clausen, C. U. Hammer, and S. J. Johnsen, Asynchrony of Antarctic and Greenland climate change during the last glacial period, Nature, 394, 739-743, 1998.

Bowen, H. J. M., Environmental chemistry of the Elements, Academic Press, London, 1979.

Delmonte, B., J. R. Petit, and V. Maggi, Glacial to Holocene implications of the new 27,000-year dust record from the EPICA Dome C (East Antarctica) ice core, Clim. Dyn., in press, 2001.

Fuhrer, K., E. W. Wolff, and S. J. Johnsen, Timescales for dust variability in the Greenland Ice Core Project (GRIP) ice core in the last 100,000 years, J. Geophys. Res., 104, 31,043-31,052, 1999.
Guilderson, T. P., L. Burckle, S. Hemming, and W. R. Peltier, Late Pleistocene sea level variations derived from the Argentine Shelf, G3 (Geochemistry, Geophysics, Geosystems), 1, 2000.

Krinner, G., and C. Genthon, Tropospheric transport of continental tracers towards Antarctica under varying climatic conditions, Tellus, submitted, 2002.

Legrand, M., Chemistry of Antarctic snow and ice, Journal de Physique, C1, 77-86, 1987 .

Legrand, M., and R. J. Delmas, Soluble impurities in four Antarctic ice cores over the last 30,000 years, Ann. Glaciol., 10, 116-120, 1988.

Legrand, M., C. Lorius, N. I. Barkov, and V. N. Petrov, Vostok (Antarctica) ice core: atmospheric chemistry changes over the last climatic cycle (160,000 years), Atm. Env., 22, 317-331, 1988.

Littot, G. C., R. Mulvaney, R. Röthlisberger, R. Udisti, E. W. Wolff, E. Castellano, M. de Angelis, M. Hansson, S. Sommer, and J. P. Steffensen, Comparison of analytical methods used for measuring major ions in the EPICA Dome C (Antarctica) ice core, Ann. Glaciol.,in press, 2002 .

Lunt, D. J., and P. J. Valdes, Dust transport to Dome C, Antarctica at the Last Glacial Maximum and present day, Geophys. Res. Let., 28, $295-$ 298, 2001

Mahowald, N., K. Kohfeld, M. Hansson, Y. Balkanski, S. P. Harrison, I. Prentice, M. Schulz, and H. Rodhe, Dust sources and deposition during the last glacial maximum and current climate: A comparison of model results with paleodata from ice cores and marine sediments, J. Geophys. Res., 104, 15,895-15,916, 1999.

McCulloch, R. D., and S. J. Davis, Late-glacial and Holocene palaeoenvironmental change in the central Strait of Magellan, southern Patagonia, Palaeogeogr. Palaeoclim. Palaeoecol., 173, 143-173, 2001.

Mulvaney, R., R. Röthlisberger, E. W. Wolff, S. Sommer, J. Schwander, M. A. Hutterli, and J. Jouzel, The transition from the last glacial period in inland and near-coastal Antarctica, Geophys. Res. Let., 27, 2673-2676, 2000 .

Reader, M. C., I. Fung, and N. McFarlane, The mineral dust aerosol cycle during the Last Glacial Maximum, J. Geophys. Res., 104, 9381-9398, 1999.

Röthlisberger, R., M. Bigler, M. Hutterli, S. Sommer, B. Stauffer, H. G. Junghans, and D. Wagenbach, Technique for continuous high-resolution analysis of trace substances in firn and ice cores, Environ. Sci. Techn., 34, $338-342,2000$.

Schwander, J., J. Jouzel, C. U. Hammer, J. R. Petit, R. Udisti, and E. Wolff, A tentative chronology for the EPICA Dome Concordia ice core, Geophys. Res. Let., 28, 4243-4246, 2001.

Steig, E. J., D. L. Morse, E. D. Waddington, M. Stuiver, P. M. Grootes, P. A. Mayewski, M. S. Twickler, and S. I. Whitlow, Wisconsinan and Holocene climate history from an ice core at Taylor Dome, western Ross Embayment, Antarctica, Geografiska Annaler, 82A, 213-235, 2000.

Stenni, B., V. Masson-Delmotte, S. Johnsen, J. Jouzel, A. Longinelli, E. Monnin, R. Röthlisberger, and E. Selmo, An Oceanic Cold Reversal during the last deglaciation, Science, 293, 2074-2077, 2001.

Vaughn, B., J. W. C. White, M. Delmotte, M. Trolier, O. Cattani, and M. Stievenard, An automated system for the uranium reduction method of hydrogen isotope analysis of water, Chem. Geol., 152, 309-319, 1998.

Watanabe, O., K. Kamiyama, H. Motoyama, Y. Fujii, H. Shoji, and K. Satow, The palaeoclimate record in the ice core at Dome Fuji station, East Antarctica, Ann. Glaciol., 29, 176-178, 1999.

R. Röthlisberger, R. Mulvaney, and E. W. Wolff, British Antarctic Survey, High Cross, Madingley Road, Cambridge CB3 0ET, England, UK.

M. Bigler and S. Sommer, Climate and Environmental Physics, University of Bern, Sidlerstr. 5, 3012 Bern, Switzerland.

M. Hutterli, Department of Hydrology and Water Resources, University of Arizona, Harshbarger Building 11, Tucson, Arizona 85721, USA.

J. Jouzel, IPSL/Laboratoire des Sciences du Climat et de l'Environnement, CEA/DSM CE Saclay, 91191 Gif-sur-Yvette, France. 


\section{Correction to "Dust and sea salt variability in central East Antarctica (Dome C) over the last 45 kyrs and its implications for southern high-latitude climate" by R. Röthlisberger et al.}

Received 16 January 2003; published 6 March 2003.

INDEX TERMS: 3344 Meteorology and Atmospheric Dynamics: Paleoclimatology; 0368 Atmospheric Composition and Structure: Troposphere-constituent transport and chemistry; 1620 Global Change: Climate dynamics (3309); 9310 Information Related to Geographic Region: Antarctica; 9900 Corrections. Citation: Röthlisberger, R., R. Mulvaney, E. W. Wolff, M. A. Hutterli, M. Bigler, S. Sommer, and J. Jouzel, Correction to "Dust and sea salt variability in central East Antarctica (Dome C) over the last $45 \mathrm{kyrs}$ and its implications for southern high-latitude climate"' by R. Röthlisberger et al., Geophys. Res. Lett., 30(5), 1216, doi:10.1029/2003GL016936, 2003.

[1] In the paper "Dust and sea salt variability in central East Antarctica (Dome C) over the last 45 kyrs and its implications for southern high-latitude climate" by Regine Röthlisberger, Robert Mulvaney, Eric W. Wolff, Manuel A. Hutterli, Matthias Bigler, Stefan Sommer, and Jean Jouzel [Geophys. Res. Lett., 29(20), 1963, doi:10.1029/ 2002GL015186, 2002], an incorrect version of Figure 1 was published. The correct Figure 1 and its caption appear below.

[2] The following reference appeared incorrectly. The correct version follows: Delmonte, B., J. R. Petit, and V. Maggi, Glacial to Holocene implications of the new 27,000year dust record from the EPICA Dome C (East Antarctica) ice core, Clim. Dyn., 18(8), 647-660, doi: 10.1007/s00382001-0193-9, 2002. Consequently, the correct citations for this reference appear below.
[3] In paragraph [7], the last sentence should read as follows: The changes seen in nss- $\mathrm{Ca}^{2+}$ concentrations agree with insoluble dust measurements [Delmonte et al., 2002], with particle number and mass concentration changing by a factor of 50 from the LGM to the Holocene and a factor of 2 from the ACR to the Holocene.

[4] In paragraph [9], the fifth sentence should read as follows: These results are supported by dust particle measurements [Delmonte et al., 2002], which showed a slightly smaller particle mode and a smaller geometric standard deviation of the particle size distribution in the glacial than in the Holocene, indicative of a tendency to longer transport paths and less meridional transport. The sixth sentence should read as follows: On the other hand, based on GCM simulations Krinner and Genthon [2002] concluded that the dust transport from Patagonia to Dome C was faster during the LGM, in contrast to the studies by Lunt and Valdes [2001] and Delmonte et al. [2002].

[5] The following acknowledgment was incorrectly published. In paragraph [15], the first sentence should read as follows: Acknowledgments. This work is contribution No. 49 to the "European Project for Ice Coring in Antarctica" (EPICA), a joint ESF (European Science Foundation)/EC scientific programme, funded by the European Commission and national contributions from Belgium, Denmark, France, Germany, Italy, the Netherlands, Norway, Sweden, Switzerland, and the United Kingdom.

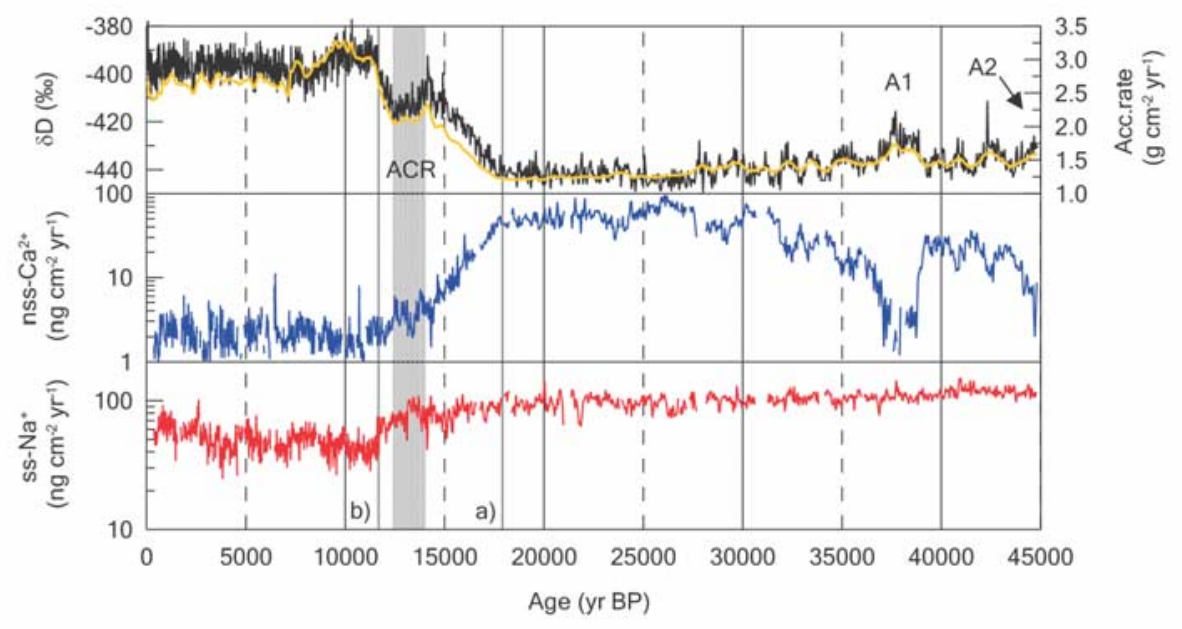

Figure 1. Fluxes of ss- $\mathrm{Na}^{+}$and nss-Ca ${ }^{2+}$, as well as the $\delta \mathrm{D}$ and the accumulation rate (yellow line, [Schwander et al., 2001]) from the top $780 \mathrm{~m}$ of the EPICA Dome $C$ deep ice core at $55 \mathrm{~cm}$ resolution. The vertical grey lines refer to the beginning (a) and the end (b) of the Transition, the shaded area corresponds to the Antarctic Cold Reversal (ACR). 